\title{
İstifhâm Edatları
}

Halil Ibrahim Kocabıyık ${ }^{1}$

\section{Öz}

Bu çalışmada fiilleri isimlere, isimleri isimlere ve cümleleri cümlelere bağlayan istifhâm edatları, görevleri ve çeşitleri ele alınmıştır. İstifhâm edatları ile ilgili dilcilerin görüşlerinden hareketle istifham edatlarının zenginliği çeşitli örneklerle ortaya konmaya çalışılmıştır. İstifhâm; daha önceden bilinmeyen bir şey hakkında onunla ilgili bilgi istemektir. Bu bilgi isteme, soru edatlarının biriyle olmaktadır. İstifhâm edatları on bir tane olup bunların iki tanesi harftir. Geriye kalan dokuz tanesi ise isimdir. İsim denmesinin sebebi, nahiv açısından mübteda, haber, fâil, mef'ûl vb. görevlerde bulunabilmeleridir. Harf olanlar ise bu görevlerde bulunmazlar. İstihâm edatı esas gayesinin dışında pek çok farklı manalar için de kullanılabilmektedir.

Anahtar Kelimeler: Edat, i̇stifhâm Edatları.

\section{Interrogatives}

\section{Abstract}

Interrogatives which are among the prepositions performing important functions by connecting verbs to nouns, nouns to nouns or sentences, their functions and views of linguists about them are handled in this study. Interrogatives are used for asking for information about something unknown before. This is performed by one of these interrogatives. There are eleven interrogatives and two of them are letters. Nine of the rest are nouns. The reason why they are called nouns is that they may have functions such as noun clauses, indicatives, subjects, passives, etc. in terms of syntax. However, the letter ones do not have these functions. Interrogatives may be used also for many different meanings apart from their main purposes.

Keywords: Preposition, Interrogatives.

1 Öğr. Gör. Uşak Üniversitesi, İslami illimler Fakültesi, Arap Dili Belâgatı Anabilim Dalı, ibrahim.kocabiyik@usak.edu.tr

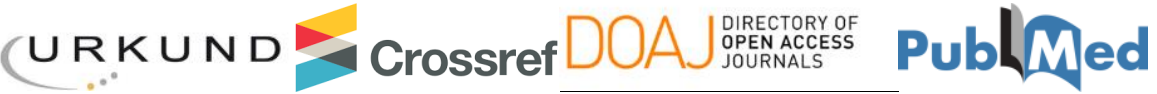




\section{Giriș}

Arap dili belâgatının, bir ilim dalı olarak ortaya çıkmasının en önemli sebebi, Arap olmayan milletlerin i̇slam'a girmesiyle, Kur'ân'ı okuyup anlama istekleri sonucunda bu dilin öğrenimine olan ilginin artmasıdır. Yabancıların dil öğrenmeye başlamasıyla da dil hataları zuhur etmeye başlamıştır. Bu durum, dönemin ilim çevrelerini konu üzerinde düşünmeye sevk etmiştir.

Arap dili belâgatı çalışmaları, dil bilimcilere göre hicri birinci asırda başlamış ve daha sonraki dönemlerde, tefsir, hadis, fıkıh vb. ilimlerin yayılmasıyla da gelișmesini sürdürerek zamanımıza kadar gelmiştir.

İstifhâm, belâgatın bir bölümü olan meânî ilminin üslûplarındandır. Sorunun teşkili ise istifham edatlarıyla mümkündür. Bu makalede, istifhâm edatlarının vazifeleri, asli anlamlarının dışında kullanılması ve alanın uzmanlarının konu ile ilgili görüşleri örneklerle ele alınıp incelenecektir.

\section{A)isstifhâm (Soru)}

\section{1) Lugat Anlamı}

İstifhâm kelimesinin sülâsîsi (فَ) "f-h-m"nin temel anlamı; kalp ile bilmek, anlamak, algılamak anlamlarına gelirken, istif'al babından olan "istefheme" ise başkasından bir şeyi kendisine anlatmasını istemektir (erRâzî, 1999:244).

\section{2) Terim Anlamı}

İstifhâm: Daha önceden bilinmeyen bir şey hakkında bilgi edinmeyi talep etmektir (esSekkâkî, 2000:308).

Râğıb el-i̇sfahânî (ö. 502/1109), istifhâmın asıl manasını, "Birinden bilgi, mal vb. şeyler vermesini ya da bunlara ulaştıracak yolu göstermesini istemektir." şeklinde tarif etmektedir (Râğıb el-i̇sfahânî, 1992:432).

Bilgi istemek ve sormak gibi hususlar soru edatlarının biriyle olmaktadır.

\section{B) İstifhâm Edatları ve Vazifeleri}

\section{1) İstifhâm Edatları}

İstifhâm edatları on bir tane olup bunların iki tanesi harf, dört tanesi isim ve beș tanesi ise zarftır. Harf olan soru edatları: " " ve olup genel olarak "mı-mi" anlamına gelirler. İsim

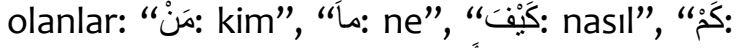
kaç” dır. Zarf olanlar ise: “أَيْنَ: nerede”, "مَنَّن: ne zaman”, “أَيَّانَ: ne zaman”, “أنَّى: nerede”, "أَيّْ: hangi”, soru edatlarıdır (el-Kazvînî, t.y.:55). Harf olan "f ve هَ" hariç isim olan istifhâm edatları cümlede âmil olmaktadır. (ibn Cinnî, t.y.:227-228).

İbn Mâlik et-Tâî (ö. 672/1274)'ye göre; istifhâm edatları cümlenin başında gelirler ve cümlenin başında gelmesi zorunludur. (ibn Hişâm, 1992:I, 83). Bu edatların asıl ve umumi olanı hemzedir. Bu harfin asıl olması, “ف وَ" gibi atıf harflerinden önce gelmesinden dolayıdır (el-Murâdî, 1992:31). Hemzenin atıf harflerinden önce gelmesine şu örnekleri

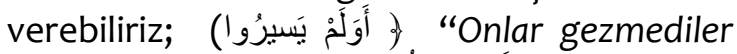

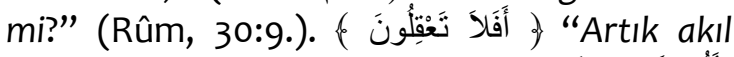

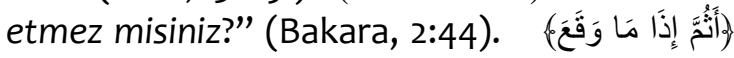
"Yoksa azap meydana geldiği zaman mı?" () (10/Yûnus, 10:51). Bu örneklerde, aslında atıf harfleri, hemzenin önüne geçmesi gerekiyordu; çünkü bu cümleler matuf cümlelerdir. Ancak hemzenin asaleti korunarak atıf harflerinden önce getirilmesi gözetilmek istenmiştir. Diğer soru edatları ise hemzenin aksine, atıf harflerinden sonra gelmektedir. (el-Murâdî, 1992:31).

ez-Zemahşerî (ö. 538/1143)'ye göre; “istifhâm edatı hemzenin ve atıf harflerinin her birinin kendi yerinde gelmesi için hemzeden sonra yerine göre uygun bir cümle takdir edilmesi..." gerekmektedir. Bu görüşünü

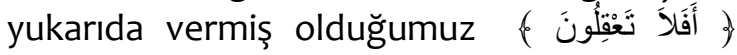
örneği ile bu şekilde ortaya koymaktadır. )

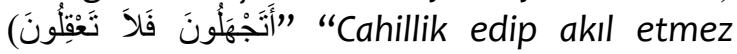
misiniz?” (el-Murâdî, 1992:31). 


\section{2) İstifhâm Edatlarının Vazifeleri}

İstifhâm edatları yaptıkları görevleri bakımından üç bölümde incelenebilir. (esSuyûtî, 2009:IV, 5).

\section{a) Tasdik Amaçlı Kullanılan هَ "hel" Edatı ve Özellikleri}

1) هَلْ "hel" edatı, sadece tasdik amaçlı kullanilır. Bu soru edatıyla tasavvur amaçlı sorular sorulamaz (es-Sekkâkî, 2000:309).

Konunun daha iyi anlaşılması için tasdik ve tasavvur terimleri üzerinde kısaca duralım.

Tasavvur, müfredi anlamak için sorulan sorudur (Antâkî, t.y.:III, 245). Yani burada öğrenilmek istenen "isnadı" içeren cümlenin tamamı değil, sadece müsnedün ileyh, müsned, mef'ûl, hâl veya zarf gibi öğelerden biridir. Bunlar da, isnad halinde olmadıkları zaman; tek başlarına bulunduklarında müfred adını alırlar. Bunu şu örnekle

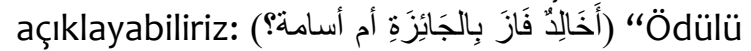
Halid mi yoksa Üsâme mi kazandı?” Bu soruda ödülün kazanılıp kazanılmadığı sorulmamaktadır. Çünkü ödülün kazanıldığı kesindir. Öğrenilmek istenen, “Ödülü kazanan kişi Halid mi yoksa Üsâme midir?” sorusunun cevabıdır. Bu çeşit sorulara cevap verirken "نَعَ" veya “لَ" sözlerinden biriyle değil, hakkında soru sorulan şey belirlenerek yapılmalıdır. Diğer bir ifadeyle böyle bir soru yönelten kimse, muhataptan kazanan kimsenin belirlenmesini istemektedir. Muhatap da "Halid" veya "Üsâme" diyerek kendisine yöneltilen soruya cevap vermiş olmaktadır (el-Mâlekî, 1985:45).

Tasdik, hükmün durumunu öğrenmektir (Antâkî, t.y.:III, 244). Yani müsned ile müsned ileyh arasındaki ilişkinin hükmü bilinmemekte ve bu hüküm öğrenilmek istenmektedir (elKazvînî, t.y.:133). Kendisine bu tarzda soru yöneltilen muhatap, müsbet (olumlu) cevap verecekse “نَ: evet”, menfi (olumsuz) cevap verecekse "V: hayır" şeklinde cevap verir (ibn Hişâm, 1992:I, 72). Bu konuyla ilgili

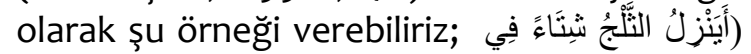
(الصَّحْرَاءِ؟ "Kışın çöle kar yağar mı?” Burada öğrenilmek istenen çöle kışın karın yağıp yağmaması hükmünün gerçekleşip gerçekleş- meyeceği hususudur. Bu soruya verilecek cevap da "نَعَمْ" veya "لَّ" sözleriyle olacaktır (ibn Hişâm, 1992:I, 72).

2) Muzâri fiilin başına geldiği zaman fiilin anlamını "س" ve "سوف" varmış gibi şimdiki zamanı gelecek veya geniş zamana dönüştürür (Antâkî, t.y.:IIl, 245). Şu ayeti

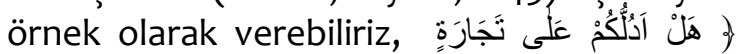
(Sizi can yakıc bir azabtan kurtaracak, kazançlı bir yolu size göstereyim mi?" ( Saff, 61-10). Ayette geçen "هَ" soru

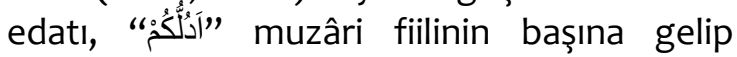
anlamını geniş zamana dönüştürmüştür.

3) " "هَلْْ "Soru edatı ile daha önce herhangi bir bilgi sahibi olunmayan şeyler hakkında soru

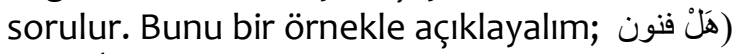
(البلاغة أحبيت "Belâgat sanatlarını sevdin mi?" şeklinde soru soran kimsenin konu hakkında ön bilgisinin olmadığı ve bu sebeple "هَل "هَ" ile

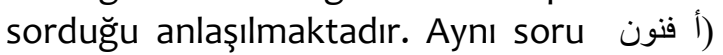
"hemze” ile sorulacak olsaydı, soruyu soran kimse bu ifadesiyle, senin hakkında belâgat sanatlarını sevdiğin düşüncesinde olduğunu ve bu düşüncesini sana doğrulatmak istediği anlaşılırdı ( Abbâs, 1997:183).

Şiirden İmru'u'l-Kays (ö. 520/565)'ın Muallaka'sından istifhâm ile ilgili şöyle bir örnek getirebiliriz;

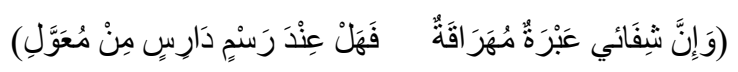

“Benim şifam bol bol gözyaşı dökmektir. Fakat silinip giden izlerin yanında ağlamak neye yarar?" (ibn Kuteybe, 1983:50). Şair burada daha önce herhangi bir şekilde bilgi sahibi olmadığını bu sebeple gelip geçici şeylere ağlamanın faydasızlığını vurgulamaktadır.

4) Yukarıda ifade ettiğimiz gibi hemze hariç diğer soru edatları atıf harflerinden sonra gelmektedir. "هَّ" de bunlardan birisidir. Bunu bir örnekle açıklayalım,

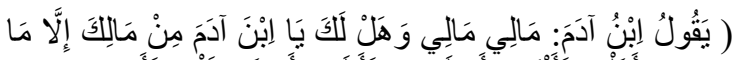

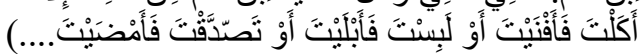

"Âdemoğlu malım, malım der, acaba ey Âdemoğlu, malından yeyip tükettiğin, giyip eskittiğin, sadaka verip ahirette karşılığını gördüğünden başka senin bir malın var mı?" (Müslim, 1992: Zühd 3-4). Bu hadiste 
görüldüğü gibi “هَ" istifhâm edatından önce atıf harfi gelmiștir.

5) Olumsuz cümlelerin, şart edatlarının, atıf harflerinin ve إنّ nin dahil olduğu cümlelerin başında "هَّ" soru edatı gelmez (el-Murâdî, 1992:342). Aşağıda verdiğimiz örneklerde "هل soru edatının kullanımı yanlıștır. Bu cümlelerde "هَّ" yerine "hemze" kullanılmalıdır. Aşağıdaki örneklerde olduğu gibi...

a. Olumsuz fiil cümlesinin başında

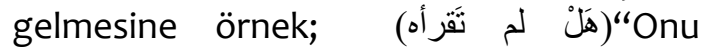
okumadın mı?” ( el-Ġalâyînî, 1993: III, 267).

b. Olumsuz isim cümlesinin başına gelmesine örnek; (هَلْ أنا لست عاقِاًَ) "Ben akıllı değil miyim?” (ibn Hişâm, 1992:IV,328).

c. Şart edatlarının bulunduğu cümlenin başında gelmesine örnek; هَّ (َ) (أقم تقر? "Ben kalkarsam sen kalkar mısın?" (ibn Mâlik et-Tâî, 1990:IV,88).

d. إنّ" edatının başında gelmesine örnek; (هل إنَّه لثاعر؟) "O şair midir?” (erRâcihî, 1999:302).

6) İbn Mâlik (ö. 672/1273), el-Kisâî (ö. 189/805), el-Ferrâ (ö. 207/822) gibi bir kısım nahiv bilginleri “هَّ" soru edatının “قَّ" manasına gelebileceğini ifade etmektedirler. (el-Murâdî, 1992:344). Bunu ayetten bir

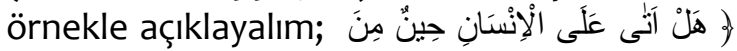

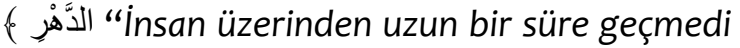
mi” (İnsan, 76-1). Ayette geçen "هَ" soru

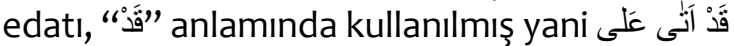

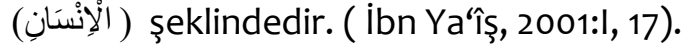

7) “هَ"in özelliklerinden biri de "nefiy" anlamına gelmesidir. $\mathrm{Bu}$ durumda

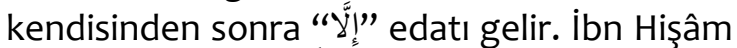
(ö. 761/1360), أَقَامَ إلإلَّ زَيدْ؟ cümledeki istisnayı, "istisna müferrağdır" şeklinde tarif eder. Bu istisna çeşidi "nefiy" edatından sonra gelir. "Hemze" olumsuzluk manasına gelmediğinden dolayı burada hemzenin soru edatı olarak gelmesi doğru olmaz. Doğrusu, هَلْ قام) (إلا زيد "Ancak Zeyd ayağa kalkmıștır." şeklinde olmalıdır (ibn Hişâm, 1992:IV, 334).
Âyetten de şu örneği verebiliriz; وَهَلْ نُجَازِي (إلاَّ الْكَافُورَ لمiz nankörden başkasına ceza mı veririz?" (Sebe', 34-17). Burada “هَ", nefiy edatı"لy" anlamındadır. (el-Murâdî, 1992:342).

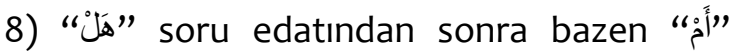
edatı geldiği görülebilir. Nahiv âlimleri buna "أمَ" munkati“ ismini vermektedirler ve bu şekilde gelmesi "idrap” için olduğunu yani “بَّن bilakis" anlamına geldiğini ifade etmektedirler. Bu çeşit kullanımlarda “أم" edatının öncesiyle sonrası arasında benzerlik ve denklik bulunmaz ( Abbâs, 1997:180). Şu

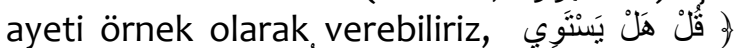

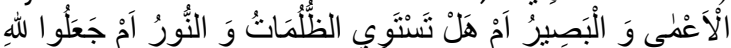

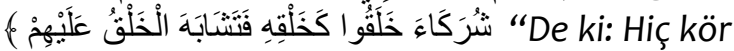
ile gören bir olur mu yahut karanlıklar ile nûr bir olur mu? Yoksa Allah'a O'nun yarattığı gibi mahlûkat yaratan ortaklar buldular da yaratana benzer mi oldular?" (Ra'd, 13:16) Bu ayette "إم" edatı öncesi ile sonrası arasında benzerlik ve denklik kurmak için değil “idrab” içindir ( el-Ġalâyînî, 1993: III, 247).

\section{b) Sadece Tasavvur Amaçlı Kullanılan Soru Edatları}

"Hemze"nin dışındaki bütün istifhâm edatları, sadece tasavvur için gelirler. (ibn Hişâm, 1992:IV, 325). Aşağıda örnekleriyle beraber inceleyeceğimiz soru edatlarından "أي mu'rab olup diğerleri mebnîdirler (Yusuf Hasan, 1978:202). Bunlar isim oldukları için cümlede onun bir öğesi olmaktadır (İbn Ya'îş, 2001:I, 17).Bunu bir misalle açıklayalım: ( مَنَى (ذَهَبْنَ؟ (Ne zaman gittin" sorusunun cevabı (كَهَبْتُ صَبَاحًا) "Sabahleyin gittim." șeklinde olur. Dikkat edilirse, soru edatı "منى"n cevabı, "صَبَاحًاء" kelimesidir ve cevap cümlesinde mef'ûlün fih olmaktadır. Öyleyse bunun sorusu olan "متى" edatı da "ذَهَبَتَّ" fiilinin mef'ûlün fihi olur (Yusuf Hasan, 1978:204).

Şimdi bu soru edatlarını sırayla ele alalım:

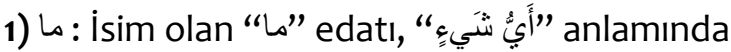
(Soyupek, 2011:219). olup bu edat ile akıllı olmayan cinslerin fertleri sorulur. İsim olduğundan dolayı diğer isimler gibi i'rabda mahalli vardır. (es-Sekkâkî, 2000:310). Kullanıldığı yerler şöyledir: 
a) Bir ismin açıklanmasını veya şerhini istemek için kullanılır. Bunu bir örnekle açıklayalım, (ما النُضَّارُ) “Nüdâr nedir?" şeklinde bir soru yöneltildiğinde; (ذَهَبْ (Sَ) "altın" kelimesini zikretmekle cevap verilir ya da "Her şeyin özünden elde edilen şeydir." şeklinde şerhi yapılarak açıklanır. (Habenneke, 1996:202).

b) Müsemmanın (kendisine isim verilen şeyin) hakikatının açıklanmasını istemek: Örnek; (مَا الحَسَدُ؟ْ) “Haset nedir?" Burada "hased" kelimesinin hakikati sorulmaktadır. Bu soruya da, (تَنَّي زوالِ النِعََْة عن المحسود) "Haset edilen kimsenin elinde bulunan nimetin yok olmasını temenni etmektir." şeklinde cevap verilir (Habenneke, 1996:203).

c) Bir şeyin sıfatı, özel ve genel durumunu öğrenmek için bu edatla sorularak açıklanmak istenir. Bunu ayetten bir örnekle

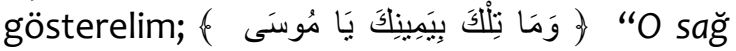
elindeki de ne Ey Musa?" (Tâhâ, 20:17).

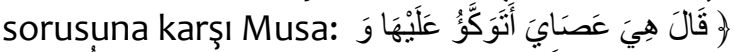

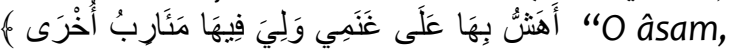
üzerine dayanırım ve onunla davarlarıma yaprak çırparım, benim ona daha başka ihtiyaçlarım da vardır." (Tâhâ, 20:18). diyerek âsanın özel ve genel durumlarılya cevap vermiştir. (el-Herevî, 2000:Il, 852).

2) : مَنْ وَ مَنْ ذَا : Akılllı varlıklar için soru edatı

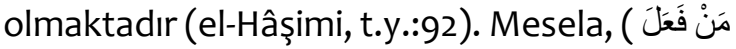
(هَ) “( هَنْ ذَا مُسافِرِ) (Yolcu kimdir?" cümlelerinde işi ve yolculuk yapan kimseyi belirlemek için sorusu sorulmuştur. Şu âyette, (Günahları Allah'tan başka kim mağfiret eder?" (Âl-i İmrân, 3:135). Burada “من"le günahları bağışlayanın sadece Allah olduğu "من" edatıyla belirlenmiştir. Bu cümledeki " "مَنْ"

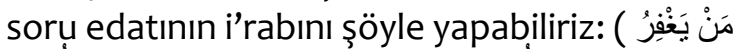

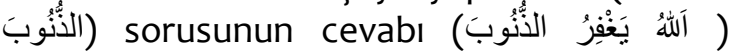
şeklinde olur. Cevap cümlesindeki soru edatı “"َْ"nin cevabı, “الهُ” lafzı olup mübtedadır. Öyleyse " "مَ" de mübtedadır, sonucuna varırız. ( Iibn Ya'îş, 2001:l, 423).

3) : Geçmiş ve gelecek zamanda soru sormak için kullanılır (Yusuf Hasan, 1978:202). İsim olduğundan dolayı diğer isimler gibi i'rabda mahalli vardır (es-Sekkâkî, 2000:313). Bu konuya ayetten bir örnek verecek olursak, (o مَتَى نَصْرُ اللهِ م) “Ne zaman Allah'ın yardımı?” (Bakara, 2:214). Şiirden de 'Amr b. Kulsûm (ö. 600 [?])'un Muallaka'sından söz konusu olan bu edat için şöyle bir örnek getirebiliriz:

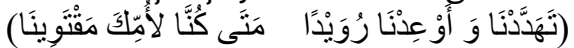

"Bizi tehdit edip gözdağı verirken biraz yavaş ol bakalım, biz ne zaman senin annenin uşağı olduk?" (ibn Kuteybe, 1983:157).

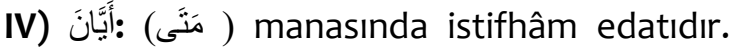
Dehşetli ve önemi büyük meseleler için kullanılır. İsim olduğundan dolayı diğer isimler gibi i'rabda mahalli vardır (Yusuf Hasan, 1978:204). Şu ayeti örnek olarak

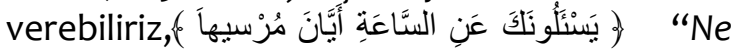
zaman demir atacak" diye sana kıyametten soruyorlar." (A'raf, 7:187).

v) كَيْْ: edatı durum ve durumun tayini için kullanılır ( ez-Zerkeșî, 1958:330). Sîbeveyh bu edatın daima zarfiyet üzerine mansub olduğunu ifade etmektedir. (İbn Hişâm, 1992:III, 132). Bunu ayetten bir örnek ile

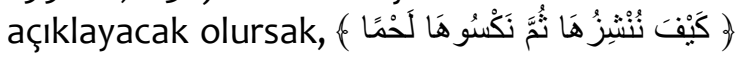
"Onları nasıl düzenliyor, sonra ona nasıl et giydiriyoruz." (Bakara, 2:259).

Şiirden de Lebîd b. Rabî‘a (ö. 41/661)'nın Muallaka'sından “" "كَيْف için şöyle bir örnek getirebiliriz:

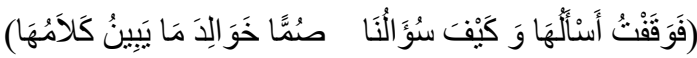

"Durup o (sevgiliyi) sordum. Gerçi konuşamayan ve sürekli (burada durup bundan sonra da) duracak olan sağıra sorumuz nasıl olur?" (ibn Kuteybe, 1983:194). İsim olduğundan dolayı diğer isimler gibi i'rabda mahalli olup, çeşitli i'rab yerlerinde bulunmaktadır. "sكيف" soru edatının i'rabını bulabilmek için soruya verilen cevapta “كَ" karşılığı olan kelimenin i'rabını bilmek yeterlidir. (Yusuf Hasan, 1978:206). " edatının i'rabını basit bir cümle ile inceleyelim: (كَيْنَ جِنْنَ "Nasıl geldin?"

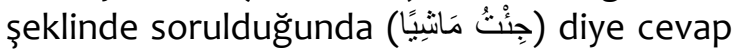
verilir. Cevap cümlesinde "كيف" nin karşıllı̆ı

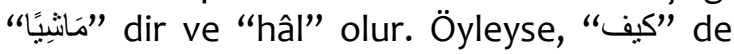
"hâl”dir (Antâkî, t.y.:III, 195).

VI) :َيْن: Mekânın belirlenmesi için kullanılır. İsim olup fetha üzerine mebnîdir. Diğer isimler gibi i'rabda mahalli vardır (es-Sekkâkî, 
2000:315). Bunu ayetten bir örnek ile

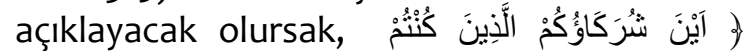

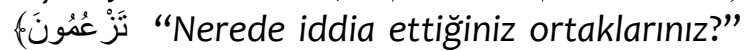
(En’âm, 6:22). Ayetinde “ايَّن” nerede anlamına kullanılmıştır.

Şiirden de Lebîd b. Rabî‘a (ö. 41/661)'nın Muallaka'sından bir örnek getirebiliriz:

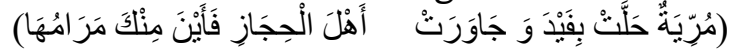
"(Sevgilim Nevâr) Murre kabilesindendir. (Bazen) Feyd'de ikamet eder, (bazen de) Hicazlılara komşu olur. Peki ya sen nerede, onu kendine râm etmek nerede?" (Ibn Kuteybe, 1983:194).

VII) أنَّ: Bu soru edatı üç anlamda olup şöyle özetlenebilir: (ez-Zerkeșî, 1958:249).

a) مينْ آَيْنَ :Nereden?" anlamına gelmektedir. Buna ayetten bir örnek verelim,

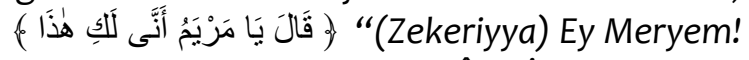
Bu sana nereden dedi." (Âl-i İmrân, 3:37).

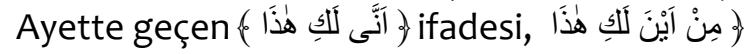
(s anlamındadır.

b) كَيْنَ: “Nasıl?" anlamına gelmektedir

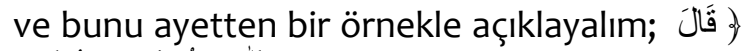
(Zekeriyya): Ey Rabbim! Benim için bir oğul nasıl olur? dedi." (Âl-i

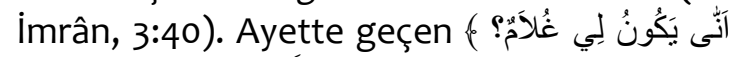

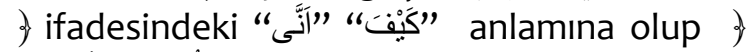

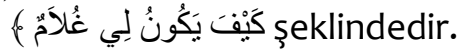

c) : "Nerede" anlamında olup, bir

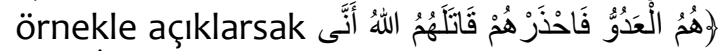

6 “ يُوَْْفَكُون "Onlar düşmandırlar, onun için onlardan sakın! Onları Allah gebertsin, nerede çevriliyorlar!" (Münafikûn, 63:4). Ayette

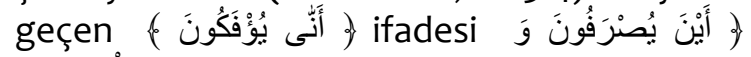

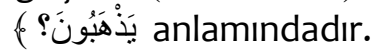

VIII) كَ : Bir şeyin adedini ve cinsini öğrenmek için kullanılan bu edatın aslı (أَ كَم) şeklinde iken ifadede kolaylık olsun diye tahfifleştirildi. (es-Sekkâkî, 2000:312). Bu edat, delalet ettiği şeyin hakikatini yani cinsini ve sayısını tek başına açıkça ortaya koyamadığından dolayı mübhem/kapalı bir kelimedir. Bu kapalılı̆̆ını gidermek için bir temyize intiyaç duyar. (Antâkî, t.y.:III, 189). " "كَ"i istifhâmiyye ve haberiyye olmak üzere ikiye ayrılmaktadır. "كَ"i istifhâmiyyeye şöyle bir örnek verebiliriz, (كَمْ قَلَمًا إِثْنَرَيْنَ) “Kaç kalem satın aldın?" "كم"i haberiyye için de Züheyr b. Ebî Sulmâ (ö.608 [?])'nın Muallaka'sından bir örnek getirelim;

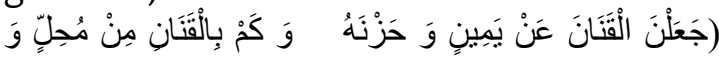

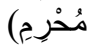

"el-Kanânı ve sarp yerlerini sağa aldılar, elKanân'da nice dostumuz da düşmanımız da var." (ibn Kuteybe, 1983:76).

Nahiv âlimlerinin büyük bir kısmı, istifhâm edatları " hariç kendisinden sonra gelen isimlere muzaf olmayacağına dair görüş birliği yapmıştır. ibn Hişam da bu görüştedir. O’na göre; “آيَ” hariç istifhâm isimleri, şart isimleri ve ism-i mevsuller hiçbir zaman muzaf olmazlar." açıklamasında bulunup konuyu şu örnekle açıklamaktadır, بَكَمْ دِزْهَ)

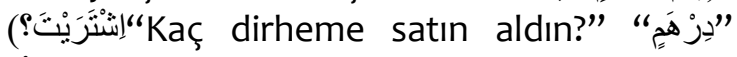
(ibn Mâlik, 1982:1705). kelimesi mahzuf olan

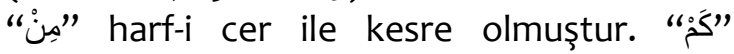
istifhâm edatının muzaf olmasıyla değildir (Ibn Hişâm, 1992:IV, 27).

Nahiv bilginlerine göre, bu edat isim olduğundan dolayı diğer isimler gibi i'rabda mahalli vardır. Cümledeki konumuna göre merfu, mansub ve mecrur olur. Mebni olmasından dolayı da i'rabını mahallen alır (Habenneke, 1996:268). "كم" soru edatının i'rabını bulabilmek için soruya verilen cevapta "كم"in karşılığı olan kelimenin i'rabını bilmek yeterlidir (Akdağ, 2016:348). Bunu birkaç örnekle açıklamaya çalışalım.

Mef'ûlün bih olmasına örnek; (كَمْ كِنَابًَا فَرَأُتَ) “Kaç kitap okudun?” sorusunun cevabı (َََْرَ

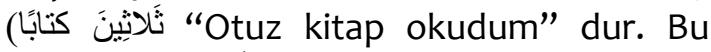
cümledeki " "كَنَّ" kelimesi soru cümlesindeki "ك"in cevabı olup mef'ûlün bihtir. Bu durumda soru cümlesindeki "كم" de mef'ûlün bihtir (Antâkî, t.y.:III, 190). Mübtedâ olmasına şöyle bir örnek verebiliriz; (كَمْ ليرَةً عِنْدَكَ) “Kaç

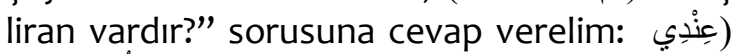

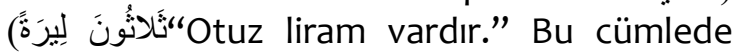
"كelimesidir ve mübtedâdır. Bu durumda soru cümlesindeki "كم" de mübtedâdır. Haber olmasına örnek;

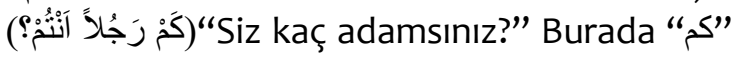
edatı haberdir (Antâkî, t.y.:III, 190). Soruya verilen cevaptan i'rabının ne olduğu anlaşılmaktadır. Mastar olmasına örnek; كَّ)

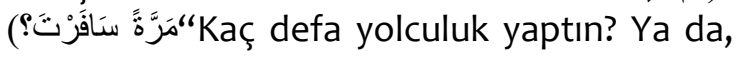


“Kaç defa yolculuk yaptım?” şeklinde mastar olmaktadır. Soruya verilen cevaptan anlaşılmaktadır. Zarf olmasına

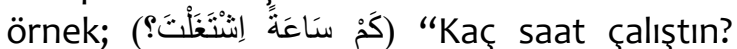

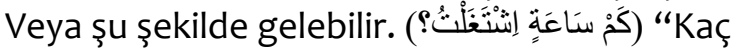
saat çalıştım?"gibi... Burada "كم" edatı zarftır. Yine cevaptan hareketle anlaşılmaktadır. "كم"den sonra gelen ifadeden temyizin ne olduğu anlaşוlıyorsa temyiz düşürülebilir. Şu örnekte olduğu gibi;

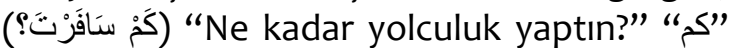
Burada mef'ûlü mutlaktır. Çünkü yolculuğun kaç defa yapıldığı zımnen anlaşılmaktadır (Antâkî, t.y.:III, 190). Takdiri (كَمْ مَرَّةً سَافَرَزتَ) şeklindedir.

IX) أب : Ortak yönleri bulunan iki şeyden birisini diğerinden ayırmak için kullanılır (elKazvînî, t.y.:232). Manasını, muzafı olduğu kelimeden (muzafun ileyhden) alır. Başka bir ifadeyle, muzafı olduğu kelimenin türüne göre, akıllı veya akılsız varlıklardan, zamandan, halden, mekândan ve sayıdan soru sorulabilir (Habenneke, 1996:269).

“أيün akılsız varlık hakkındaki soru şekline

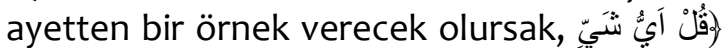

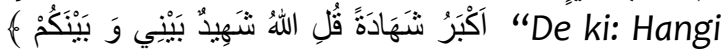
şeyin şahitliği en büyüktür? De ki: Allah benimle sizin aranızda şahittir." (En'âm, 6:19). "أي edatının hal oluşuna 'Amr b. Kulsûm'un Muallakasından bir örnek getirelim,

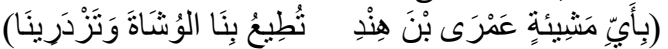

"Ey Hind oğlu 'Amr! Nasıl oluyor da, ispiyonculara kulak verip bize hakaret edebiliyorsun?" (Ceviz-Demirayak, 2010:137). “"أَيّ İsim olduğundan dolayı diğer isimler gibi i'rabda mahalli vardır ( İbn Ya'îş, 2001:I, 21). I'rabdaki durumunu şu örnekte inceleyelim:

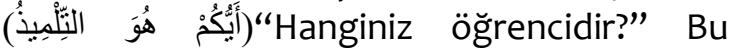
sorunun cevabı da "Ahmet öğrencidir." şeklinde olur. Cevap cümlesindeki " "حَحَّ" soru cümlesindeki “'أَيّ cevabı̈ı ve mübtedâdır. O halde "أَيّ" de mübtedâdır (elKazvînî, t.y.:232).

\section{3) Hem Tasdik Hem de Tasavvur Amaçlı Kullanılan Soru Edatı "hemze"}

"Hemze" hem tasdik hem de tasavvur amaçlı (es-Suyûtî, 2009:II, 211). kullanılan soru edatı olup "هل" soru harfinin sahip olduğu bütün özellikleri de içine almaktadır (CârimEmîn, t.y.:I, 411).

Bu edatın kendine has bazı özellikleri vardır. Bunları maddeler halinde sıralayabiliriz:

I). Cümlelerin Başına Gelir.

Hemze, isim ve fiil cümlelerinin her ikisinin de başına gelmektedir (el-Mâlekî, 1985:44).

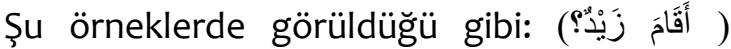
“Zeyd ayakta mı?” ve (أقَام زيدُ) "Zeyd ayağa kalktı mı?”

II) Sorulan şey, Daima Hemzeden Sonra Gelir (ez-Zerkeşî, 1958:178).

Sorulup öğrenilmek istenen şey daima hemzeden sonra gelmesi gerekir ( Abbâs, 1997:171).

Bu konuyu değişik örneklerle açıklayalım, Çaydanlıkta çay mı yoksa kahve mi olduğu bilinmediğinde; أشناي في الإبريق أم ("قهوة؟Çaydanlıkta çay mı yoksa kahve mi vardır?" şeklinde sorulması gerekir. Muhammet'in yolculuktan geldiği biliniyor ama uçakla mı yoksa arabayla mı geldiği bilinmediğinde; (أجاء محمد بالطائرة أم بالسيارة؟) Soru hemzesinden hemen sonra (جاءة الطاء) fiilini getirmek doğru olmaz. Çünkü Muhammet'in geldiği bilinmektedir ama ne ile geldiği bilinmemektedir. Tasavvur için sorulan şey, soru hemzesinden hemen sonra gelmesi gerektiğinden şu şekilde sorulması gerekirdi; (أبالطائرة جاء محمد أم بالسيارة؟) "Muhammet uçakla mı yoksa arabayla mı geldi?” Yukarıdaki örneklerde görüldüğü gibi sorulan şey, daima hemzeden sonra gelmektedir.

İmru'u'l-Kays (ö. 25/645)'ın Muallakasından da konuyla ilgili şu örneği getirebiliriz,

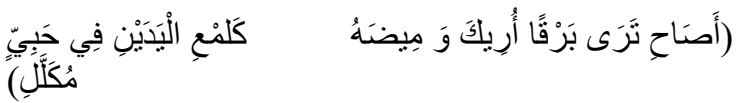

"Taç giymiş kat kat bulutların içerisinde hareket eden iki elin parlayışı gibi çakışını sana gösterdiğim şimşeği görüyor musun, arkadaş?” (Ceviz-Demirayak, 2010:49). Bu 
misalde de görüldüğü gibi sorulan şey soru edatından sonra gelmektedir.

\section{III) Hemze Tasavvur İçin de Gelebilir}

Hemze tasavvur için olduğunda, “أَ” atıf harfinden sonra, hakkında soru sorulan ve hemzeden hemen sonra gelen öğeye denk veya benzer bir öğe getirilmelidir (el-Mâlekî, 1985:45). Anlam karmaşası olmaması için hakkında soru sorulan şeyin, hemen soru hemzesinden sonra gelmesine ve ayrica muadilinin de "أم" atıf harfinden sonra gelmesine ve ona uygun olmasına özen gösterilmelidir. Örneğin; "yolcunun Zeyd mi yoksa Amr mı olduğu" öğrenilmek istendiğinde şöyle sorulur: أزَيد مسافر أم) (عمرو؟"Zeyd mi yoksa Amr mı yolcudur?" Burada عمرو kelimesi, زيد kelimesinin dengi ve benzeridir. Çünkü her ikisi de müsnedün ileyhdir. Bu soruyu şöyle sormamız uygun değildir: (أمسافر زيد أم عمرو؟) Bu sorudaki denkler ( مسافر ve عمرو ) birinin iş, oluş ve davranış göstermesi diğerinin de isim olması bakımından uyumsuzdurlar. Şayet müsnedün ileyh değil de müsned sorulacak olursa bu takdirde hemzeden hemen sonra gelmiş olan müsnedün durumuna benzer veya dengi olarak iş, oluş, davranış gösteren bir kelime olması gerekir. Örneğin, bu soruyu şöyle sormamı mümkündür: (أمسافر زيد أم مقيم؟) "Zeyd yolcu mu yoksa mukim midir?" (Abbâs, 1997:172). Hakkında soru sorulan şeyin muadili, muhatab tarafından algılanıyorsa muhatabın anlayışına dayanarak muadilin hazf edilmesi mümkündür (el-Mâlekî, 1985:45). Örnek; "Muhataptan babasının evde olup olmadığı" öğrenilmek istendiğinde şöyle sorulur: (أفي الدار أبوك؟) "Baban evde midir?" Aslında bu soru şöyle sorulmalıydı: Baban evde mi yoksa işte midir?" Burada soruyu soran muhatabın anlayışına itimat ederek muadili hazf etmiş olmaktadır (Abbâs, 1997:172).

IV) Hemze Atıf Harflerinden Önce Gelir Yukarıda da ifade ettiğimiz gibi hemze atıf harfleriyle birlikte geldiğinde, asıl olması sebebiyle, atıf harflerinden önce gelmektedir (ez-Zerkeşî, 1958:173). Abbâs'ın konuyla ilgili görüşü şu şekildedir: Hemze, istifhâm edatlarının en asılı olması sebebiyle atıf harflerinin kendisinden önce gelmesi mümkün değildir (Abbâs, 1997:175).

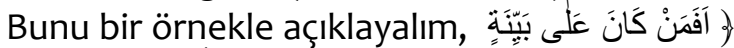

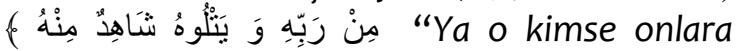
benzer mi ki, o artık Rabbinden bir delil üzerinde bulunmuş, hem bunu O'ndan bir şahid takip ediyor,..." (Hûd, 11:17). Ayette soru edatı olan hemze, atıf harfi olan "ف" den önce gelmiştir.

Diğer istifham edatları ise atıf harflerinden sonra gelmektedirler. Örnek;

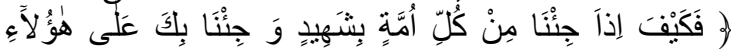

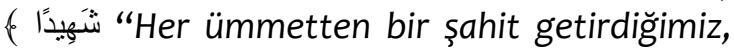
seni de onların üzerine şahit getirdiğimiz vakit bakalım nasıl olacak!" (Nisâ, 4:41). Burada "كيف" "ف "atıf harfinden sonra gelmiştir.

Buraya kadar istifhâm edatlarını örneklerle tanıtmaya çalıştık. Bu edatlar asıl anlamlarının dışında başka anlamlara da gelebilmektedir. Bunlara da değinmek yerinde olacaktır.

\section{Soru Edatlarının Asıl Anlamlarının Dışında Kullanımları}

İstifhâm'ın, esas manası olan "bilinmeyen bir şey hakkında bilgi istemek" olduğunu yukarıda belirtmiştik. Bunun yanında esas gayesinin dışında pek çok farklı manalar için de kullanılabilmektedir (el-Kazvînî, t.y.:234241).

el-Murâdî (ö. 749/1348), “istifhâm'ın hakiki manası asıl olmakla birlikte yerine göre başka manalar da murat edilebilir." (el-Murâdî, 1992:31). șeklinde bir ifadede bulunmaktadır.

Bunların en önemlileri şunlardır:

\section{1) Emir (الامر)}

İstifhâmın hakiki manasından çıkıp emir manasına gelmesidir (es-Sübkî, 2003:I, 461).

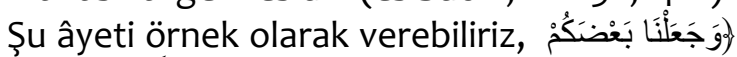
(Bir de bazınızı diğerine bir fitne kılmışızdır ki bakalım sabredecek misiniz?" (Furkân, 25:20). Bu ayette ki "اتَصْنْرُونَنَ" istifhâm edatı

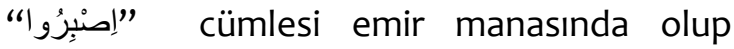
"sabrediniz" anlamına gelmektedir (Ebû Hayyân, 2000:VIII, 95). 


\section{2) Nehiy (النهي)}

İstifhâm hakiki manasından çıkıp nehiy anlamına gelebilir. Yani istiğla yoluyla bir fiilin yapılmaması soru edatıyla talep edilebilir (Atîk, 2009:I, 107). Bunu bir örnekle

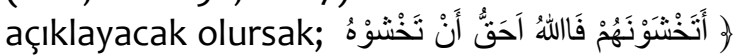
"Yoksa onlardan korkuyor musunuz? Eğer mü'minseniz, daha önce Allah'tan korkmalısınız." (Tevbe,9:13). Bu

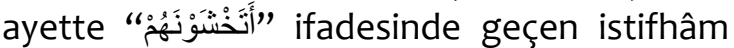
edatı olan hemze, aslında(لآنَخْشَوْهُم) “Onlardan korkmayınız?" manasına olup, nehiy ifade eder (Habenneke, 1996:291).

\section{3) Eşitlik (التسوية)}

Bu üslupla, eşitlik manası istifhâm yoluyla ifade edilir. Bu edat aynı zamanda kendisinden sonra gelen kelimeye mastar manası verir ve muadili de zikredilir (ibnu'lVerâk, 1999:455).

Bu konuya örnek olarak şu ayeti verebiliriz; $)$

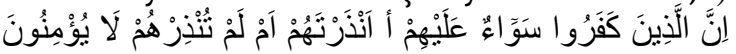
(6 "O küfre saplananları uyarsan da uyarmasan da birdir. Imana gelmezler." (Bakara, 2:6). Küfre düşenler daha önce kendilerinin uyarıldıklarını biliyorlar ama buna rağmen küfürlerinde ve inatlarında ısrar ediyorlardı.

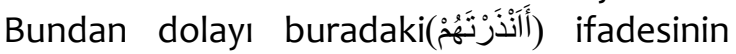
başındaki “i”” hemze edatı, eşitlik manasındadır (et-Taberî, 2001:I, 264).

\section{4) Olumsuzluk (النفي)}

İstifhâm edatları nefiy manasında gelebilirler. Bu durumda kendilerinden sonra gelen cümlelerin manalarını menfiye çevirirler. Eğer mazi fiil cümlesinin başına gelirlerse (لَمْ يَكُنْ) “olmadı", muzari fiil cümlesinin başına gelirlerse (لا يكون) “olmaz" manasında olurlar ( el-Bedevî, 2005:126). Kur'ân-ı Kerim'de istifhâm edatının olumsuzluk manasına geldiğine dair pek çok örnek bulunmaktadır. Bunlardan bir kaç tanesine göz atalım; "Artık Allah'ın şaşırttığını kim yola getirebilir?" (Rûm, 30:29). Burada geçen istifhâm edatı (لا هادي لمن أضلّ الله) "Allah'ın şaşırttığını yola getiren hiç kimse olamaz" anlamındadır (el-Alûsî, 1995:VII, 379). Yine şu

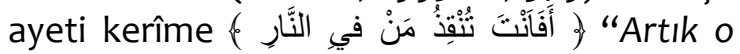

ateşteki kimseyi sen mi çıkaracaksın?" (Zumer, 39:19). (ولست تتقذ من في النار) "Ateşteki kimseyi sen çıkaramazsın." anlamına gelmek suretiyle nefy ifade eder (ez-Zerkeşî, 1958:II, 328). Bu örneklerde istifhâm edatları, olumsuzluk manası içermektedirler (Atik, 2009:I, 75).

İstifhâmın olumsuzluk manasına geldiğine dair el-Bühturî (ö. 248/897)'den bir örnek getirebiliriz,

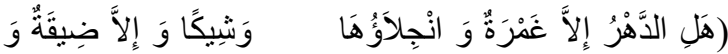

$$
\begin{aligned}
& \text { انْفِرَ اجُهَا) }
\end{aligned}
$$

"Dünya sıkıntı ve o sıkıntının süratle ortadan kalkmasından başka bir şey midir? Ve o sıkıntı olup sıkıntının ortadan kalkmasıyla onun ardından rahatlığın meydana gelmesinden başka bir şey değildir." (Cârim-Emîn, t.y.:197). Bu örnekte geçen istifhâm "olumsuzluk" manasını ifade etmektedir.

\section{5) İnkâr (hoş karşılamama) (الانكار)}

Sevilmeyen, hoşlanılmayan ve kabul edilmeyen bir durumu istifhâm yoluyla ifade etmektir (ibn Manzûr, 1990:III, 273). İstisna edatı, nefiy edatlarının biriyle geldiği gibi, inkâr manasında kullanılan istifhâm edatlarıla da gelebilmektedir (es-Suyûtî, 1988:328). Olumlu cümlelerin başına geldiklerinde manalarını olumsuza çevirirler.

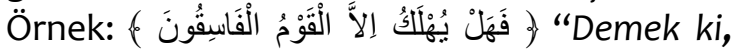
helak edilecek başka değil, ancak taatten çıkmış fasıklar güruhudur (Ahkâf, 46:35). etTaberî (ö. 310/923)'ye göre, âyette geçen (هل) istifhâm edatı, nefiy (ما) anlamında olup

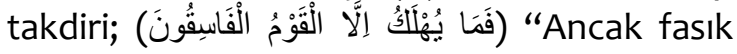
kavimler helak olur." Anlamındadır (etTaberî, 2001:XXI, 178). Olumsuz cümlenin başında geldiğinde olumlu mana katar (Habenneke, 1996:263). Olumsuz cümlelerin başına geldiğinde manalarını olumluya

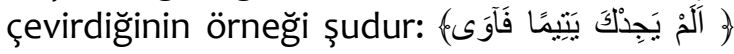
"Seni öksüz bulup da barındırmadı mı?" (Duha, 93:6).

İnkâr, tekzîbî ve tevbîhî olmak üzere ikiye ayrilır. 


\section{a) Tekzîbî İnkâr:}

Tekzîbî inkâr, bir şeyin yalanlanmasını soru ifadesiyle ifade etmektir (Bulut, 215: 216)

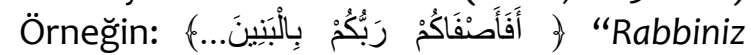
oğulları sizin için ayırıp seçti de,..." (İsra, 17:40). Bu ayette geçen istifhâm edatı "لَمْ يَفْعَ) (نَلِّabbin böyle yapmadı.” manasında olup inkârcıların uydurdukları şeyleri yalanlamaktadır (ibn Ebî Zemenîn, 2002:III,

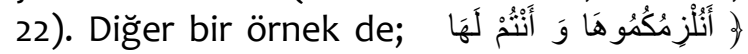
كارِ هُونَ كان (Biz size onu istemediğiniz halde zorla mı kabul ettireceğiz?" (Hûd, 11:28). Buradaki istifhâm edatı (لاَ يَكُونُ هُذَا الإلزَامَ) "Zorlama olmaz.” manasındadır (es-Suyûtî, 1974:328).

\section{b) Tevbîhî İnkâr:}

Tevbîhi inkâr, kabul edilmeyen bir şeyin kınama da içermesine denir (el-Mâlekî, 1985:46). Allah'a imanı ve itaati bırakıp

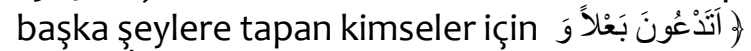

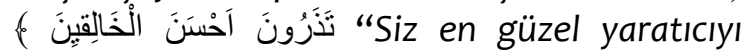
bırakıp da Ba'le putuna mı çağırıyorsunuz?"

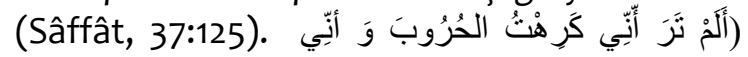

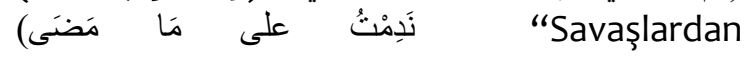
hoşlanmadığımı ve geçen şeye de pişman olduğumu görmedin mi?" denilmesi bu kabildendir (Bakırcl, 2000:25).

Ebu't-Tayyib el-Mütenebbî (ö 354/965)'nin, (Kâfûr el-Ihşîlî (ö.375/968) için yaptığı bir methiyede söylemiş olduğu sözü inkâr konusuna örnek olarak getirebiliriz,

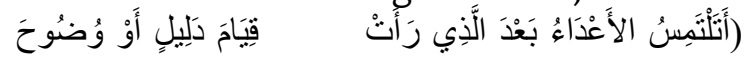

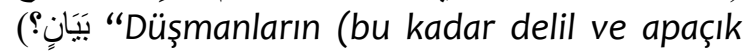
şahit) gördükten sonra, (Allah'ın seni galip kılacağına dair tekrar başka) apaçık bir delil ve bürhan mı isterler?" (Bolelli, 2001:227). Bu örnekteki istifhâm "inkâr" (yani hoş karşılamama) manasını ifade etmektedir.

\section{6) Takrîr (التقرير)}

Bir hükmü, istifhâm yoluyla muhataba itiraf ettirmek ve onaylatmaktır (ibn Hişâm, 1992:I, 95). İbrahim (a.s.)'ın "Siz putlarınızı çağırsanız onlar size cevap verebilecekler

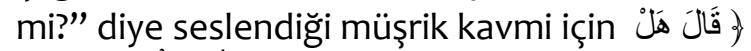

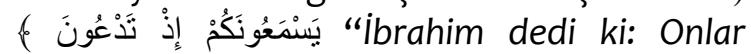
çağırdığınız zaman işitirler mi?” ibrahim'in bu sorusu karşısında putperestler cevap vermekten aciz kaldılar. Sadece taklitçi olduklarını söyleyerek şöyle dediler: "Hayır, onlar bizim dualarımızı işitmiyorlar, bize bir menfaat ve zarar da vermiyorlar. Ancak biz babalarımızın bunlara taptıklarını gördük ve biz de öyle yapıyoruz diyerek bir itirafta bulunmuş oluyorlar (et-Taberî, 2001:XVII, 589).

el-Bühturî, şöyle demiş:

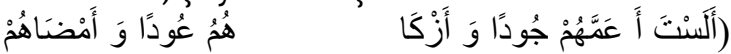

$$
\begin{aligned}
& \text { حُسَامًا؟) }
\end{aligned}
$$

"Sen onların içinde çömertliği en yaygın olan, vücudu en kuvvetli ve kılıcı en keskin olan kimse değil misin?" (Cârim-Emîn, t.y.:I, 197). Bu örnekteki istifham "takrîr" (ikrâr ettirme) manasını ifade etmektedir.

\section{7) Taaccüb (التعجب)}

Taaccüb edilen şeyi istifhâm yoluyla ifade etmektir (Habenneke, 1996:278). Örneğin şu ayeti kerîmede taaccüb, istifhâm edatıyla

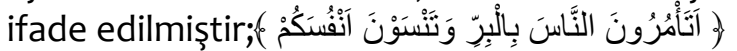
"Insanlara iyiliği emreder de kendinizi unutur musunuz?” (Bakara, 2:44). Ayetteki آََأْرُرُونَ

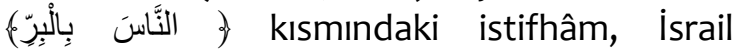
oğullarının âlimlerinin durumunun şaşılacak bir halde olduğunu ifade etmesi bakımından taaccüb ifade eder. Çükü onlar halka yapmaları gereken görevlerinin üstünde daha fazla hayırlı ameller yapmalarını emrederek onların yükümlülüklerini genişletiyorlardı. Kendileri ise emrettiklerini yapmadıkları gibi farz olan görevlerini de terk etmişlerdi (ez-Zerkeşî, 1958:I, 330). Diğer bir

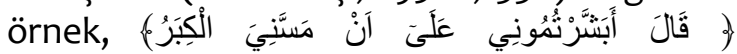
"(ibrahim:) Bana ihtiyarlık çökmesine rağmen beni müjdeliyor musunuz?" (Hicr, 15:54). Burada da yine istifhâm edatı taaccüb manasındadır. Sanki ibrahim (as) şöyle

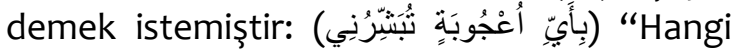
hayrete düşürücü şeyle beni müjdeliyorsun?" (Fahruddîn er-Râzî, 2000:XIX, 151).

\section{8) Hatırlatma ( التذكير)}

Bir sözü, bir eylemi veya bir olayı muhataba istifhâm yoluyla hatırlatmaktır (ez-Zerkeşî, 1958:I, 178). Bu konuya şu ayeti örnek

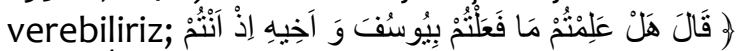
6َاهِلُونَ (Yusuf) dedi ki: Siz, cahilliğiniz yüzünden Yusuf ve kardeşine yaptıklarınızı 
biliyor musunuz?" Yûsuf, 12:89). Yusuf (a.s.), geçmiște kardeşlerinin kendisine ve kardeși Bünyamin'e karşı nasıl davrandıklarını istifhâm yoluyla hatırlatmaktadır. Buradaki hatırlatma ifadesi aynı zamanda serzeniş de içermektedir ( el-Vâhidî, 2009: XII, 232). Diğer

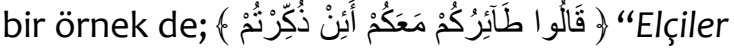
şöyle cevap verdi: Sizin uğursuzluğunuz sizinle beraberdir. Size nasihat ediliyorsa bu uğursuzluk mudur?” (Yâsin, 36:19). Elçiler, belde halkından putlara tapmaktan vazgeçmelerini istediklerinde onlar, bu istekleri uğursuz saydılar. Belde halkına uğursuz saymalarının sebebi (I) "hemze" istifhâm edatıyla hatırlatıldı eş-Şevkânî, 1993:VI, 157).

\section{9) Övünmek (الافتخار)}

İstifhâm edatlarının kullanıldığı diğer bir üslûp çeşidi de övünmek amacıyla kullanılmasıdır (ez-Zerkeşî,, 1958:I, 331). Firavun'un, Musa (a.s.)'a karşı övünmesini dile getiren şu ayeti bu konuya örnek olarak

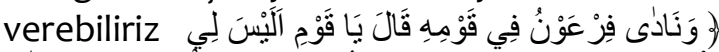

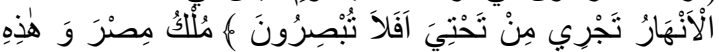
"Ve Firavun, kavminin içinde şöyle bağırdı: Ey kavmim! Mısır mülkü benim ve hep şu nehirler benim altımdan akıyor değil mi? Artık gözünüzü açsanız ya!" (Zuhruf, 43:51). Firavun, Musa (a.s.)'ın davetinden ve mucizelerinden kavminin etkilenip ona tabi olmasından korktu. Kendisinin Musa'dan üstün olduğunu ve Mısır hükümdarının Musa'nın değil kendisinin olduğunu neredeyse açıklayamayacaktı ki üstünlüğünü istifhâm yoluyla ifade etmekte buldu (Habenneke, 1996:282).

\section{0) Yüceltmek (التعظيم)}

Mütekellimin gördüğü bir şeyin yüceliğini ve muhteşemliğini istifhâm yoluyla ifade etmesidir (ez-Zerkeşî, 1958:I, 332). Yüceltmek anlamına gelen istifhâm edatına şu ayeti

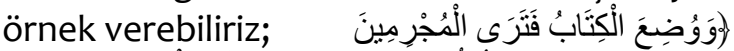

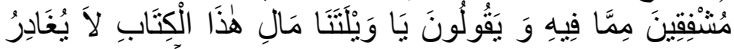
"Kitap ortaya konmuştur: Suçluların onda yazılı olanlardan korkmuș olduklarını görürsün. Vay halimize! derler, bu nasıl kitapmıș! Küçük büyük hiçbir şey bırakmaksızın (yaptıklarımızın) hepsini sayıp dökmüș! " (Kehf, 18:49). Günahkârların kıyamet gününde amel defterlerini aldıklarında bir de ne görsünler ki küçük olsun büyük olsun hepsini bu defterler içerisine almışlar. Onlar, hiçbir şeyi dışarıda bırakmayan bu defterlerin azâmetini ve fehâmetini istifhâm yoluyla ifade etmişlerdir (Habenneke, 1996:283).

Konuyla ilgili Ebu't-Tayyib'in mersiyesinden de bir örnek verelim:

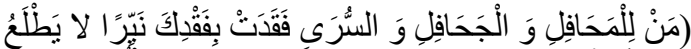

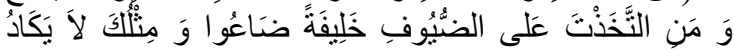

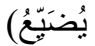

"Artık toplantılar, ordular ve gece baskınları için kim var? (Halk), seni kaybetmekle (tekrar) doğmayacak bir güneși kaybetti. Misafirlere bakmak için halef olarak (yerine) kimi bıraktın? Onlar, zayi oldular (yok oldular), Senin gibiler, neredeyse zayi etmezler." (Cârim-Emîn, t.y.:I, 197). Bu örnekte geçen soru edatı olan (مَنْ) "tazim ve yüceltme" manasını ifade etmektedir.

\section{1) Dehşete Düşürmek (التهويل)}

Korkunç ve dehşet verici bir şeyle karşılaşıldığında bu durumu istifhâm ile ifade etmektir (ez-Zerkeșî, 1958:I, 332). Örneğin şu

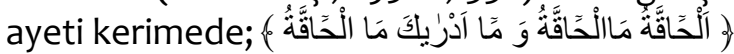
“Gerçekleşecek gün. Nedir o gerçekleşecek gün? Gerçekleșecek gün sana dirayetle ne bildirdi?" (Hâkka, 69:1-3). Yüce Allah, kıyametin korkunç ve dehşet verici durumunu istifhâm yoluyla yani "م" istifhâm edatını iki kere tekrar etmek suretiyle ifade etmektedir (ibn Âşûr, 2000:XXX, 449).

\section{2) Tehdit Etmek (التهديد)}

Mütekellimin istifhâm metoduyla muhatabını tehdit etmesidir (Atik, 2009:83).

Örneğin, Mürselât suresindeki şu ayette geçen istifhâm edatı tehdit manası

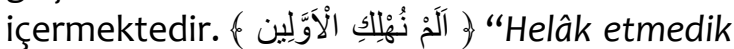
mi evvelkileri?” (Mürselât, 77:16). Allah, ilk asırlarda yaşamış mücrimleri hatalarından dolayı helak etti. Daha sonra gelen ümmetler de öncekiler gibi davranırlarsa onları da helâk edeceğine dair tehdidini istifhâm yoluyla anlatmaktadır (Atik, 2009:83). Diğer bir

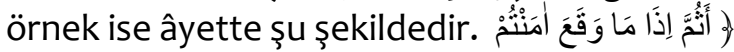


(َبَ “Başınıza belâ geldikten sonra mı O'na iman edeceksiniz." (Yûnus, 10:51). Bu âyette geçen istifhâm edatı tehdit manasındadır (esSemerkandî, 2010:Il, 120). Kur'ân'da bu manaya gelen pek çok örnek vardır.

\section{3) Uyarmak (التنبيه)}

Uyarmak, gerçekte emrin kısımlarından olup emir sığasında kullanılan manaları istifhâm yoluyla ifade etmektir (Atik, 2009:84). Bu

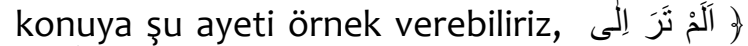
(Rabbinin gölgeyi nasıl uzattığına bakmaz mısın?" (Furkân, 25:45).

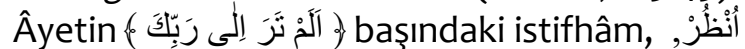
تَفَكَّ, تَنَبَّْْ ayetlerinden olan bu ayete "bak, düşün, dikkat et" gibi uyarı anlamında kullanılmıştır (ez-Zerkeşî, 1958:I, 178). Konuyla ilgili olarak

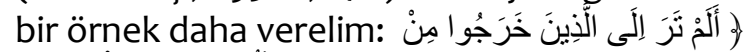
"Binlerce oldukları halde, ölüm korkusundan dolayı yurtlarından çıkıp gidenleri görmedin mi?" Bu kişilerden maksat "Vasît" ilinin yakınlarında bulunan "De-Verdan" kasabasının halkıdır. Halk, kasabada kolera hastalığı dehşet verici bir şekilde yayılmaya başlayınca ölüm korkusundan dolayı yurtlarını bırakıp kaçar. Kaçış esnasında Allah, onları önce öldürmüş sonra diriltmiştir. Âyet, halkın ibret alıp Allah'ın kaza ve kaderinden kurtulușun olmadığını istifhâm edatıyla ifade etmektedir (es-Semerkandî, 2010:II, 120).

\section{4) Bir Şeyin Geciktiğini Bildirmek (الاستبطاء)}

İstibtâ, belirlenen bir zamanın, verilen bir sözün veya beklenen bir şeyin geciktiğini istifhâm yoluyla ifade etmektir (Habenneke, 1996:294).

Bir şeyin geciktiği manasına gelen istifhâma

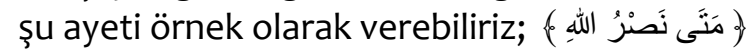
“Ne zaman Allah'ın yardımı?” (Bakara, 2:214).

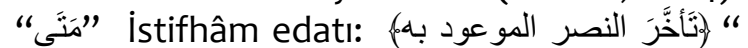
Söz verilen yardım gecikti." manasındadır. Insan işte böyle aceleci bir varlıktır. Allah'ın hikmeti, aceleci olan insanın talepleriyle mutabık olmayabilir (ibn Hişâm, 1992:I, 197). Ebu't-Tayyib el-Mütenebbî şöyle demiştir:

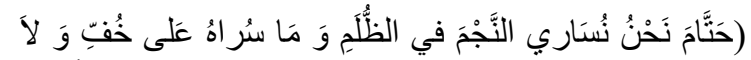
(قَ)

"Ne zamana kadar gece karanlığında yıldızlarla birlikte yürüyeceğiz? Çünkü o (yıldız) ne deve gibi tabanı (ayağı) üzerinde yürür. Ne de insan gibi ayak üzerinde yürür." (Bolelli, 2001:228). Bu örnekte "حتى"ya bitişik olarak gelen "ما" soru edatı bir işin "yavaş yapıldığı" manasını ifade etmektedir.

\section{5) Bilmezden Gelmek (التجاهل)}

Tecâhül, daha fazla tanımayı istemek, itiraf ettirmek, hakir görmek, bilmiyormuş gibi davranıp değerini azaltmak vb. durumlar sebebiyle bilmezlikten gelme durumunu istifhâm yoluyla ifade etmeye denir (ezZerkeşî, 1958:I, 331).

Bilindiği halde bilinmiyormuş gibi davranılan

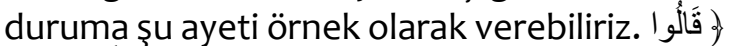

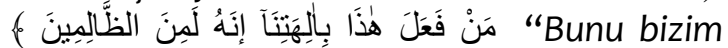
ilahlarımıza kim yapmış? Muhakkak o zalimlerden biridir, dediler." (Enbiyâ, 21:5962). Ibrahim'in kavmi, putlarına yapılan tahkirin Ibrahim (as) tarafından yapıldığını bildikleri halde bilmezlikten geldiklerini " من" istifhâm edatıyla ifade ettiler.

\section{6) Küçümseme (التحقير)}

Tahkîr, küçümseme ve alay durumunu istifhâm yoluyla ifade etmektir (Atik, 2009: I, 79). Bunu ayetten bir örnekle açıklayalım, وَ ؤ

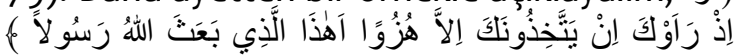
"Seni de gördükleri vakit sırf bir eğlence yerine tutuyorlar, Bu mu o Allah'ın peygamber diye gönderdiğii? diyorlar." (Furkân, 25:41). Ayette geçen (اَهذَا) istifhâm edatı küçümseme ifade etmektedir. Putların ne fayda verici ne de zarar verici oldukları apaçık ortaya çıkmasına rağmen, putları savunarak Allah'ın peygamberini küçümsediler ve onunla alay ettiler. Küçümseme durumlarını da istifhâm yoluyla ifade ettiler (Habenneke, 1996:297).

Ebu't-Tayyib el-Mütenebbî, Kâfûr el-Ihşîlî̀yi (ö. 375/968) hicvederek onu tahkir ettiğinin gösteren şu ifadeye bakalım:

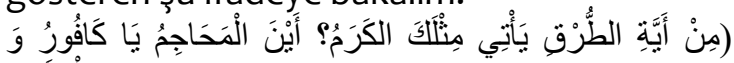

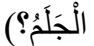

"Senin gibi birine cömertlik, hangi yollardan (nereden) gelir? Ey Kâfûr! (Kan) şişeleri nerede ve neşter nerededir? (Cârim-Emîn, t.y.:I, 197). 
Bu örnekteki soru edatları olan “أي, "أين" "küçümseme" manası ifade etmektedirler.

\section{7) Alay Etme (التهكم)}

Mütekellimin, muhatabıyla dalga geçmesi veya incitici sözler söyleyerek gülünecek duruma düşürme isteğini istifhâm yoluyla ifade etmesidir (Ibn Hişâm, 1992:I, 96).

Örneğin hûd sûresinin 87. ayetindeki istifhâm edatı, alay etme manası içermektedir: क

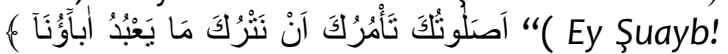
Atalarımızın taptıklarını terk etmemizi namazın mı emrediyor?" (Hûd, 11:87).

Ebû Hayyân (ö. 745/1345) bu ayette geçen istifhâm edatının alay manasına geldiğini ifade ederek şu açıklamalarda bulunmuştur: Şuayb (AS), ümmetinden Allah'a ibadet etmelerini, putlara yaptıkları ibadetleri terk etmelerini, ölçüyü ve tartıyı tam yapmalarını istediğinde, ümmeti bu davete karşı çıktı. Karşı çıkmakla da kalmadılar: (أَصَلاُثُكَ) “Namazın mı?" (أكَان كثير الصلاة) “Namazı çok olan mı" gibi bunlara benzer sözler söyleyerek alay ettiler, eğlenceye aldılar kahkaha atıp gülüștüler (Ebû Hayyân, 1995:V, 253).

\section{8) Serzeniş (العتاب )}

Mütekellimin, bir şeyden pek de hoşnut olmadığını muhataba istifhâm yoluyla ifade etmesidir (Habenneke, 1996:280).

Şu ayette Allah'ın mü'minlere karşı yaptığı serzenişi örnek olarak verebiliriz;

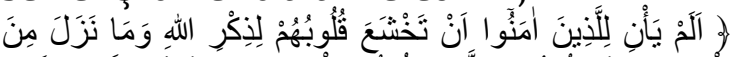

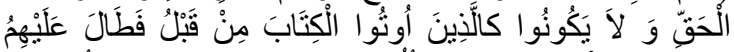

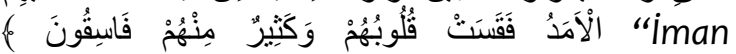
edenlerin Allah'ı anma ve O'ndan inen Kur'ân sebebiyle kalplerinin ürpermesi zamanı daha gelmedi mi? Onlar daha önce kendilerine kitab verilenler gibi olmasınlar. Onların üzerinden uzun zaman geçti de kalpleri katılaştı. Onlardan birçoğu yoldan çıkmış kimselerdir." (Hadîd, 57:16). Bu ayette, iman edenlerden bir grubun, iman etmelerinin üzerinden yeterli derecede vakit geçmesine rağmen kalpleri huşu ile dolması gerekirken tam aksine imanla bağdaşmayan işlere dalmaları istifhâm ile ifade edilerek serzenişte bulunulmaktadır (Habenneke, 1996:280).

\section{9) Çokluk (التكثير)}

Mütekellimin, çok olan bir şeyi istifhâm yoluyla ifade etmesidir. Burada çoğunlukla kullanılan istifhâm edatı "كَ" dir. Bu durumda " edatı istifhâm edatı olmaktan çıkarak " "S"i haberiye adıyla ifade edilir (ez-Zerkeşî, 1958:I, 331). Bunu bir örnekle açıklayalım, के

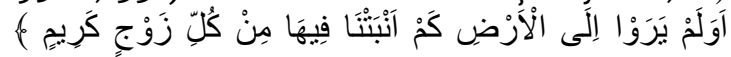
"Yeryüzüne bir bakmadılar da mı biz onda her hoş çiftten ne kadar bitirmişiz? (Şuarâ, 26:7). Bu ayette Yüce Allah'ın yeryüzünde pek çok çeşit bitkiler bitirdiğini, istifhâm yoluyla ifade etmesinden anlamaktayız (Habenneke, 1996:287).

\section{0) Teşvik (الترغيب)}

Teşvik, gerçekte emir sığasında kullanılır ama emir manasına gelen istifhâm yoluyla da kullanılabilir (Atik, 2009:84). Teşvik manasına gelen istifhama örnek olarak şu ayeti

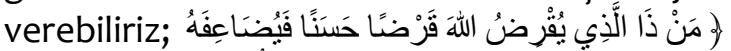

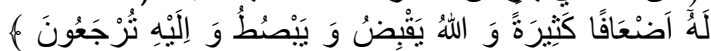
“Allah'a güzel bir borç verip (malını O'nun yolunda harcayıp) da karşılığını kat kat ilave edilmiş olarak geri alamayan kimdir? Allah darlık da verir, genişlik de. Hepiniz O'na döndürülüp götüreleceksiniz." (Bakara,

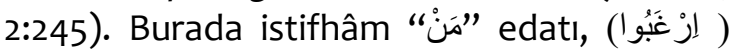
sığası yerinde gelmiştir. Haydin Allah'a güzel bir şekilde borç veriniz de bu borç karşılığında büyük bir sevap elde ediniz? (Habenneke, 1996:290).

\section{Sonuç ve Öneriler}

Kur'ân- Kerim'in Arapça olarak indirilmesinin ardından Arap dili daha büyük ilgi görmüş ve diğer dillere nazaran daha detaylı incelemelere tabi tutulmuştur. Bu çerçevede çalışmamız "Arapçada İstifhâm Edatları" konusunun, özellikle hem meânî ilmindeki hem nahiv ilmindeki yeri ve önemi hususunda daha belirgin olarak ortaya çıkmasına vesile olacaktır. Bu makale istifhâm edatlarının âyetlerde, hadislerde ve Arapça edebi metinlerde ne kadar düzenli, disiplinli ve çeşitli kullanıldığını ortaya koymaktadır.

illahiyat fakültelerinde Arapça öğretimi meslekî öğretim açısından çok önem 
kazanmıştır. Ancak Arapça ile ilgili yapılan uygulamalarda hâlen bazı eksiklerimiz bulunmaktadır. İstifhâm edatlarını derslerimizde öğretirken sadece hakiki manalarından bahsedip mecâzi anlamlarını bir kenara bırakmamız büyük bir eksikliktir. Çünkü bu eğitim yuvalarında yetişen öğrencilerin en önemli özellikleri hatipliktir. Hatip olan bir kimse, hitap ettiği kimselere sorular yönelttiğinde veya kendisine sorular yöneltildiğinde bunların mecâzi anlam içeriklerini de hemen kavraması gerekmektedir. Çalışmamı bu manada Arapça istifhâm edatlarının mecazi yönden zenginliğini de ortaya koymaktadır.

İstifhâm edatlarının asıl anlamları dışında kullanımı bilinmezse cümlelere yanlış veya farklı anlamlar verilebilir. Bu ise özellikle ayet ve hadislerin yanlış anlaşılmasına sebep olacağından geri dönülmez vahim hatalara sebep olur. Bundan dolayı istifhâm edatlarının doğru kullanılması ve anlaşıması mühimdir.

\section{Kaynakça}

Abbâs, F.H (1997), el-Belâgiatu Funûnuhâ ve Efnânuhâ 'Ilmu'l-Meânî, Dâru'l-Furkân, Yermûk.

Abbâs, H. (t.y.), en-Nahvu'l-Vâfî, Dâru'lMeârif, Mısır.

Akdağ, H. (1987), Arap Dilinde Edatlar, Konya. el-Cârim, A.-Emîn, M. (t.y.), en-Nahvu'I-Vâdıh fî Kavâ'ıdi'l-Luğati'l-'Arabiyye, ed-Dâru'lMisriye, y.y.

el-Alûsî, Ş.M. (1995), Rûhu'l-Meânî fî Tefsîri'lKurâni'l-'Azîm ve's-Seb'u'l-Mesânî, (tah. Ali Abdilbârî Atıyye), Dâru'l-Kütübi'l-IImiyye, Beyrut.

Antâkî, M. (t.y.), el-Muhît fî Usûli'l-Arabiyye ve Nahvihâ ve Sarfihâ, Beyrut.

Atîk, A. (2009), Ilmu'l-Meânî, Dâru'n-Nehda, Beyrut.

Bakırcı, S.-Çöğenli, M. S. (2000), Arapça Edatlar Sözlüğü, Erzurum.

el-Bedevî, A. B. (2005), Nehdâ Mısır, Kahire.
Bolelli, N. (2001), el-Belâğâtu'l-Arabiyye, İstanbul.

Bolelli, N. (2006), Mu'cemu Mustalahâtı'nNahvi ve's-Sarfi, Yasin Yayınevi, İstanbul.

Bulut, A. (2015), Belâgat Terimleri Sözlüğü, istanbul.

Ebû Hayyân, M.Y. (2000), el-Bahru'l-Muhît fi't-Tefsîr, (tah. Sıtkî Muhammed Cemîl), Dâru'l-Fikr, Beyrut.

Ebû Hayyân, M.Y. (1995), en-Nehru'l-Mad Mine'l-Bahrı'l-Muhit (tah. Ömer Esad) Beyrut.

Ege, R. (2010), Kelâmın Muktezây-ı Hâle Mutâbakatı, İzmir.

Fahruddîn er-Râzî, E.A. (2000), Muhammed b. Ömer b. el-Hasan b. el-Hüseyin, Mefâtîhu'lĠayb (et-Tefsîru'l-Kebîr, Dâru ihyâu't-Türâsi'lArabî, Beyrut.

Habenneke, A.H. (1996), el-Belâğatu'l'Arabiyye, Beyrut.

el-Hâşimi, A. (t.y.), Cevâhiru'l-Belâğa fî'l-Meânî ve'l-Beyân ve'l-Bedii', Dâru ihyâ't-Türâsi'lArabî, Beyrut.

el-Herevî, 'A.M.N. (1981), Kitâbu'l-Uzhiyye fî 'ilmi'l-Hurûf, (tah. 'Abdulmu'în el-Mellûhî, Dımaşk.

el-Herevî, E.S.M. (2000), İsfâru'l-Fasîh, (tah. Ahmed b. Sa'îd b. Muhammed Kaşşâş), Suûdiye.

el-Enbârî, E.B.K. (1995), Esrâru'l-'Arabiyye, (tah. Fahr Sâlih Kudâra), Dâru'I-Cîl, Beyrut.

İbn Cinnî, E.F.O. (t.y.), el-Lem'u fi'l-'Arabiyye, (tah. Fâiz Fâris), Dâru'l-Kütübü's-Sekâfiye, Kuveyt.

İbn Ebî Zemenîn, E.A.M. (2002), Tefsîru'lKur'ân, (tah. Ebû Abdillah Hüseyin b. UkâşâMuhammed b. Mustafa el-Kenz), Kahire.

İbn Hișâm, 'A.Y. (1997), Şerhu Kadri'n'-Nedâ ve Belli's-Sadâ, Beyrut.

İbn Hișâm, C.A. (1992), Muğni'l-Lebîb 'an Kutubi'l-E'ârîb, (tah. Muhammed Muhyiddîn 'Abdulhamîd, Beyrut.

Ibn Mâlik, E.'A.M. (1982), Şerhu'I-Kâfiye'şŞâfiye, (tah. 'Abdulmun'im Ahmed Hureyrî, y.y. 
ibn Mâlik et-Tâî, E.A.C. (1990), Şerhu Teshîli'lFevâid, ( tah. Abdurrahman es-SeyyidMuhammed Bedevî el-Mahtûn), y.y.

ibn Manzûr, C.M.M. (1990), Lisânu'l-'Arab, Dâru'l-Fikr, Beyrut.

Ibn Ya'îș, E.B.A. (2001), Şerhu'l-Mufassal, (tah. İmîl Bedî‘ Ya‘kûb), Dâru'l-Kütübü’lilmiyye, Beyrut.

el-Murâdî, H.K. (1992), el-Cene'd-Dânî fî hurûfi'l-Me'ânî, (tah. Fahruddîn Kabâ ve Muhammed Nedîm Faâzıl), Beyrut.

ibnu'l-Hâcib, Cemâluddîn Ebû 'Amr 'Usmân b. Umer, el-Kâfiye, Salân Bilici Kitabevi, İstanbul, t.y.

ibnu'l-Verâk, E.H.M. (1999), 'llelu'n-Nahv, (tah. Muhammed Câsim Muhammed edDervîş), Mektebetü'r-Rüşd, Riyad.

el-Kazvînî, H.M. (t.y.), el-izâhh fi Ulûmi'l-Belâğa, Dâru'l-Cîl, Beyrut.

el-Mâlekî, A.'A. (1985), Rasfu'l-Mebânî fî Șerhi Hurûfu'l-Me'ânî, (tah. Ahmed Muhammed elHarrât), Dımaşk.

Müslim, E.H.H. (1992), el-Camiu's-Sahîh, Çağrı Yayınları, İstanbul.

Ceviz, N.- vd. (2010), Yedi Askı, Ankara.

er-Râcihî, A. (1999), et-Tatbîku'n-Nahvî, Mektebetü'l-Maarif, y.y.

Râğib el-i̇sfahânî, E.K. (1992), el-Mufredât fî Ġarîbi'l-Kur'ân, (tah. Safvân Adnân edDâvudî), Dâru'l-Kalem, Beyrut.

er-Râzî, E.A.Z. (1999), Muhtâru's-Sihâh, (tah. Yûsuf eş-Şeyhu Muhammed), Beyrut.

es-Sabân, M.A. (1997), Hâşiyetu's-Sabân 'alâ Şerhi'I-Eşmûnî li-Elfiye íbn Mâlik, Şebeketü Müşkâti'l-İslâmiye, Beyrut.

es-Sekkâkî, E.Y.Y. (2000), Miftâhu'l-Ulûm, Dâru'l-Kutubi'l-ilmiyye, Beyrut.

es-Semerkandî, E.L.N. (2010), Bahru'l-'Ulûm, Dâru'l-Kütübü'l-ilmiyye, y.y.

Soyupek, H. (2011), Arap Dilinde Mâ Edatı ve işslevleri, Ankara.

es-Suyûtî, C.A. (t.y.), Hem'u'l-Hevâmi' fî Şerhi Cem'ı'l-Cevâmi' (tah. Abdülhamîd Handâvî), Misır.
es-Suyûtî, C.A. (2009), Kitâbu'l-Eşbâh ve'nNezâir fi'n-Nahv, (tah. Gâzî Muhtâr Talîmât), Dimeşk.

es-Suyûtî, C.A. (1988), Mu'terekku'l-Akrân fî I'câzi'l-Kur'ân, Beyrut.

es-Suyûtî, C.A. (1974), el-itkân fî Ulumi'lKur'ân, (Thk. Muhammed Ebu'l-Fadl i̇brâhîm), Mısır.

es-Sübkî, E.H.B. (2003), ‘Arûsu'I-Efrâh fî Şerhi Telhîsi'l-Miftâh, (tah. Abdülhamid Handâvî), el-Mektebetü'l-Asriyye, Beyrut.

eş-Şevkânî, E.A.M. (1993), Fethu'I-Kadîr, Nşr. el-Ma 'rife, Beyrut.

et-Taberî, E.C.M. (2001), Câmi'u'l-Beyân an Te'vîli Âyi'l-Kur'ân, (tah. Abdullah b. Abdilmuhsin et-Türkî), y.y.

el-Vâhidî, E.H.A. (2009), et-Tefsîru'l-Besît, (tah. Muhammed b. Seûd), Suûd.

ez-Zerkeșî, B.M.A. (1958), el-Burhân fî UlûmîlKur'ân, (tah. Muhammed Ebû'l-Fadl ibrahim), Dâru'l-ihyâ'l-Kutubi'l-Arabiyye, Kahire. 